\title{
Impact of integrated weed management on productivity of bread wheat and
}

\author{
associated weeds \\ Abdullah, S.Sh. ${ }^{1 *}$, K.A. Hamam ${ }^{1}$ and A.M. Abdul-Hamid ${ }^{2}$ \\ ${ }^{1}$ Department of Agronomy, Faculty of Agriculture, Sohag University, Sohag 82533, Egypt \\ ${ }^{2}$ National Food Safety Authority (NFSA, Sohag)
}

\begin{abstract}
A field experiment was conducted at a private farm in Sohag, Egypt in 2016-17 and 2017-18 to evaluate chemical weed control, planting method and seeding rate on bread wheat productivity and associated weeds. Weeding treatments were: Pyroxsulam (Pallas) herbicide and the check. Planting methods were: ridges (narrow beds); rows; dry-; and wetbroadcasting. The seeding rates were: 45,60 and $75 \mathrm{~kg} / \mathrm{feddan}\left(\mathrm{fed} .=4200 \mathrm{~m}^{2}\right.$ ). Results revealed that Pallas significantly reduced the biomass of weeds by $91 \%$ vs. the check. Wet seeding resulted in the smallest biomass of weeds vs. the dry methods. Increasing seeding rate from 45 to $75 \mathrm{~kg} / \mathrm{fed}$. significantly reduced the biomass of total weeds by $65.8 \%$. The $75 \mathrm{~kg} / \mathrm{fed}$. seed rate + Pallas significantly reduced biomass of weeds. Pallas significantly increased numbers of spikes $/ \mathrm{m}^{2}$, grains/spike and grain yield vs. the check. Pallas increased grain yield by 5.4 ardab (150 $\mathrm{kg}$ /fed. vs. the check. Ridges planting had superior effect on numbers of spikes $/ \mathrm{m}^{2}$, number of grains/spike vs. other methods. As for grain yield, ridges method was the first and rows was the second, while wet and dry methods were significantly equal in the third class. The $75 \mathrm{~kg} / \mathrm{fed}$. seed rate significantly increased spikes $/ \mathrm{m}^{2}$ and grain yield. Pallas with $75 \mathrm{~kg} / \mathrm{fed}$. rate gave the highest values of spikes $/ \mathrm{m}^{2}$ and grain yield. Ridges method with Pallas also produced the highest grain yield. The ridges method seeded by $75 \mathrm{~kg} / \mathrm{fed}$. and treated by Pallas produced the highest grain yield of $29.35 \mathrm{ardab} / \mathrm{fed}$. (10.48 t/ha) and could be recommended for producing bread wheat under similar conditions.
\end{abstract}

Keywords: wheat productivity; integrated weed management; grain yield.

\section{Introduction}

Wheat is the first staple food crop in Egypt and there is an increased demand on this vital commodity to save the food security for the growing population. There is a big gap $(\sim 42 \%)$ between wheat consumption used for food and the domestic production. Enhancing the yield per unit area and expanding the harvested area besides reducing the yield losses $(21.5 \%$ of the domestic production; FAO, 2018) are the main national targets for increasing wheat production. Although, several high yielding varieties have been developed and recently released to the farmers, the national average yield (6.38 t/ha; FAO, 2019) is

\footnotetext{
*Corresponding author: Safwat Shalaby Abdullah, Email: s.shalaby13@gmail.com

Received: June 29, 2021; Accepted: July 29, 2021;

Published online: July 30, 2021.

(C) Published by South Valley University.

This is an open access article licensed under @(i)(2)
}

still below the potential records $(8.57 \mathrm{t} / \mathrm{ha})$ achieved by (El-Bana et al., 2013).

Sowing wheat by proper method, using the adequate seeding rate and applying the effective weed control program are among the main factors suppressing weeds and improving wheat productivity. In Egypt, wheat is mainly sown via broadcasting method in one of its two paths, dry planting method (afeer) or wet sowing method (herati). However, there are some new sowing techniques controlling weeds, achieving higher yields and saving water, still the majority of farmers are using inadequate old methods. Planting on ridges (narrow beds) and rows (line sowing) are promising wheat sowing methods in Egypt. Seed driller machines used for row sowing need large areas to use in and this isn't always available and being a limiting factor. Wet sowing (herati) may control weeds better, but consumes more water, needs excess seeding rate to ensure 
good germination and crop establishment and produces fewer yields. Both ridges and row planting methods create proper environment for the individual plants to grow and to have equal quantities of growth factors. Worldwide and recently in Egypt, bed planting technique is being used for saving water, better wheat stand, easy weed management, reducing lodging and producing higher yields per unit area (Chauhdary et al., 2016; El-Sherif et al., 2016). In addition, farmers in Egypt are familiar with using ridges planting in cultivation of several field crops as corn, sorghum and faba bean.

Establishment of adequate wheat density by using proper seeding rate is needed for high yields which increase returns from other production inputs and may decrease the need for chemical weed control. Using excess seeding rate over the optimum may cause crop lodging, decrease grain yield and quality. In contrast, the lower seeding rate enhances individual plant characteristics, encourage weeds to be more competitive with wheat crop and reduce the yield. Adjusting seeding rate can optimize the ability of wheat plants to intercept and capture light energy, to efficiently use other available resources and therefore increases yield (Isidro-Sánchez et al., 2017).

Weeds are a major obstacle against improving wheat productivity. Weeds not only cause a yield reduction, but also decrease the yield quality, hinder harvesting and increase the production costs. Using herbicides is more beneficial for controlling weeds and the world is rushing to adopt herbicides for the upcoming developed agriculture (Hossain, 2015). Pyroxsulam (Pallas) is identified as a new selective weedicide belongs to new generation in chemistry of herbicides (Anonymous, 2007). However, integrated weed management programs are advisable to be applied by wheat producers where herbicide-resistant weeds are present. Integrated weed management (IWM) includes chemical and non-chemical methods like higher seeding rate, sowing method and competitive wheat varieties can be adopted to control weeds and to have good yields.

Therefore, the objective of this study aimed at evaluating the effects of planting method, seeding rate and chemical weed control (as an IWM approach) on weeds biomass, wheat grain yield and its attributes.

\section{Materials and Methods}

\subsection{Site description, planting and agronomic practices}

A two-year field experiment was conducted at a private farm $\left(26^{\circ} 43^{`} \mathrm{~N}, 31^{\circ} 78^{`} \mathrm{E}\right)$ at Ezbet El Nimr, El- Monshah district, Sohag governorate, Egypt in 2016-17 and 2017-18 seasons. The top soil $(0-30 \mathrm{~cm})$ of the farm was clay loam with $\mathrm{pH} 7.8, \mathrm{EC} 0.86 \mathrm{dS} \mathrm{m}^{-1}$ and having $2.39 \%$ organic matter. The used weeding treatments were: 1) Chemical weeding by Pallas (4.5\% O.D.) herbicide applied at 3-5 leaf stage of wheat at a rate of $160 \mathrm{~mL}$ dissolved in $200 \mathrm{~L}$ water/fed. using $20 \mathrm{~L}$ - knapsack sprayer with one nozzle. 2) Without weed control (check). Planting methods were: 1) Ridges $(60 \mathrm{~cm}$ apart, narrow beds), seeds were planted in $15 \mathrm{~cm}$ in-between hills on both sides of each ridge (double-row ridges). 2) Rows (line sowing), seeds were manually drilled into $20 \mathrm{~cm}$ apart flat rows. 3) Dry planting (afeer), seeds were broadcast on prepared flat dry soil and lightly covered into soil. 4) Wet planting (herati), soaked seeds (in tab water for 12 hours) were broadcast and incorporated into hand-tilled soil which was previously irrigated and had sufficient moisture content for seed germination and then soil surface was leveled by a farm fork. The used seeding rates were 45, 60 and $75 \mathrm{~kg} / \mathrm{fed}$. of Sids 12 bread wheat. The experimental design was RCBD in split-split plots arrangement with four replicates. Weeding treatments were in the main plots, the sub-plots were specified for planting methods and seeding rates were in the sub-subplots. The experimental area was divided into $10.5 \mathrm{~m}^{2}$ ( $\left.3 \mathrm{~m} \times 3.5 \mathrm{~m}\right)$ subsubplots. Sorghum was the preceding summer crop in both seasons of study. Sowing irrigation was given on the same date $\left(30^{\text {th }}\right.$ and $26^{\text {th }}$ Nov. in 
$1^{\text {st }}$ and $2^{\text {nd }}$ seasons, respectively) to the plots of the three dry planting methods, but it done one week before them in the plots of wet seeding (herati) method. Each sub-subplot was fertilized by agricultural gypsum $\left(\mathrm{Ca} \mathrm{SO}_{4} \cdot \mathrm{H}_{2} \mathrm{O}\right)$, mono-super phosphate $\left(15 \% \mathrm{P}_{2} \mathrm{O}_{5}\right)$, and potassium sulfate (48 $\left.\% \mathrm{~K}_{2} \mathrm{O}\right)$ at rates of 400,150 and $50 \mathrm{~kg} / \mathrm{fed}$., respectively which were added to the soil just before planting irrigation. Also, 20\% of the applied fertilizer $\mathrm{N}(90 \mathrm{~kg} / \mathrm{fed}$.) was given before planting irrigation to improve the soil fertility and activate wheat growth and tillering. The remained $80 \%$ of fertilizer $\mathrm{N}$ was split into two equal doses, the $1^{\text {st }}$ was given to wheat at three weeks after sowing while the $2^{\text {nd }}$ was applied one month later in both seasons. Other agronomic practices were kept the same for all sub-subplots and done as recommended for wheat production in the area.

\subsection{Data recorded}

\subsubsection{Weeds}

At 75 days after sowing, weeds were manually pulled from $0.25 \mathrm{~m}^{2}$ area in each sub-subplot, then separated and classified to broad- and narrowleaved (grassy) weeds, and then freshly weighed. Weeds were first air dried and then oven dried at $70^{\circ} \mathrm{C}$ until a constant weight, then dry weight of total weeds was recorded and calculated in $\mathrm{g} / \mathrm{m}^{2}$. The prevalent weed species associated with wheat plots in both seasons of study are shown in Table 1 .

Table 1. Scientific, common and family names of weed species associated with wheat crop plots in both seasons of the experiment.

\begin{tabular}{llll}
\hline Weed groups & Scientific name & Common name & Family name \\
\hline \multirow{3}{*}{ Narrow-leaved } & Avena fatua $\mathrm{L}$. & Wild Oat & Poaceae \\
& Lolium temulentum $\mathrm{L}$. & Ryegrass & Poaceae \\
& Phalaris minor Retz. & Canarygrass & Poaceae \\
\cline { 2 - 4 } & Sinapis arvensis $\mathrm{L}$. & Wild mustard & Asteraceae \\
& Cichorium pumpilum Jacq. & Chicory & Asteraceae \\
Broad- leaved & Sonchus oleraceus $\mathrm{L}$. & Sowthistle & Asteraceae \\
& Convolvulus arvensis $\mathrm{L}$. & Bindweed & Convolvulaceae \\
& Medicago intertexta $\mathrm{L}$. & Medic & Fabaceae \\
& Malva parviflora $\mathrm{L}$. & Cheeseweed & Malvaceae \\
& Rumex dentatus $\mathrm{L}$. & Dentated dock & Polygonaceae \\
\hline
\end{tabular}

\subsubsection{Wheat crop}

I- Yield attributes: At harvest, wheat plants on $0.5 \mathrm{~m}^{2}$ area from each sub-subplot were cut at soil line to determine the following traits:

1. Number of stems (main shoots + tillers $) / \mathrm{m}^{2}$,

2. Number of spikes $/ \mathrm{m}^{2}$,

3. Number of grains/spike, as an average of 10 spikes, and

4. 1000-grains weight (g), as average of two replicates.

II- Grain yield (ardab, $150 \mathrm{~kg} / \mathrm{fed}$.) was estimated from $3 \mathrm{~m}^{2}$ area of interior plants of each subsubplot.

III- Lodged wheat plants were observed visually at harvest as a percentage of lodged area and strength of lodging.

\subsection{Statistical analysis}

All data recorded in both seasons were statistically analyzed according to ANOVA technique by SAS, GLM procedure (SAS Institute, 2008). The LSD test at 5\% level of significance was used for means separation according to Gomez and Gomez (1984).

\section{Results and Discussion}

\subsection{Dry weight of total weeds}

Data presented in Table 2 show the effects of weed control, planting methods, seeding rate and their interactions on dry weight of total weeds in both seasons. Chemical weeding by Pallas 
herbicide significantly reduced $91 \%$ (average of the two seasons) of biomass of total weeds compared to the un-weeded plots. The Pallas herbicide is characterized a broad spectrum weedicide controlling both broad- and narrowleaved weeds (Anonymous, 2007), but it was more effective against narrow-leaved than on broadleaved weeds (Abdul-Hamid, 2021). The satisfied action of Pallas herbicide against the total weeds might be due to the new technology built in and its higher bio-selectivity against wheat weeds. This result of weed control would encourage wheat plants to grow and develop properly and being more yielding. The findings of Aliaa et al. (2018) are supporting this result. Planting methods didn't significantly affect the dry weight of total weeds in both seasons. However wet seeding method resulted in the smallest biomass of total weeds in contrast to the dry seeding method. Both ridges and rows methods were in-between wet and dry seeding methods in this respect. Mobarak (2008) reported that ridges-planting was superior method in controlling total weeds as compared to afir drill and afir broadcast. Similar results were also reported by Mollah et al. (2009). Increasing seeding rate from 45 to $75 \mathrm{~kg} / \mathrm{fed}$. significantly minimized the dry weight of total weeds in both seasons. As an average of the two seasons, the 75 $\mathrm{kg} / \mathrm{fed}$. seed rate reduced $65.8 \%$ of total weeds biomass compared to $45 \mathrm{~kg} / \mathrm{fed}$. (Table 2). This result might be due to the higher density of wheat plants associated with $75 \mathrm{~kg} / \mathrm{fed}$. seeding rate which made wheat plants more competitive against both broad- and narrow-leaved weeds. This result is agreed with those reported by Yadav and Jagdish (2015). The combined treatment of 75 $\mathrm{kg} / \mathrm{fed}$. seed rate and Pallas herbicide significantly resulted in least dry weight of total weeds. Yet, the interaction of $45 \mathrm{~kg} / \mathrm{fed}$. seeding rate and without weeding treatment produced the highest dry weight of total weeds in both seasons.

\subsection{Wheat crop}

\subsubsection{Stems number $/ \mathrm{m}^{2}$}

Results in Table 3 show that the Pallas herbicide significantly increased stems number $/ \mathrm{m}^{2}$ at harvest compared to the control in both seasons. This result may be due to that the Pallas was effective in controlling the competitive weeds (Table 2) which in turn gave the chance to wheat plants to produce more survival tillers per unit area. Ridges planting followed by rows method resulted in the highest number of stems $/ \mathrm{m}^{2}$ in both seasons. Meanwhile, the least number of stems $/ \mathrm{m}^{2}$ was recorded with the wet seeding method in both seasons of study. It is obvious that planting on ridges was ideal for wheat plants to produce more tillers per unit area. This method seems to be creating favorable conditions around wheat plants such as sufficient water and nutrients supplies, light penetration, $\mathrm{CO}_{2}$ concentration and other factors affecting wheat growth and development. These results are in agreement with those obtained by Kabesh et al. (2009). Increasing seeding rate from 45 to 60 to $75 \mathrm{~kg} / \mathrm{fed}$. significantly increased the number of stems $/ \mathrm{m}^{2}$ in both seasons, yet the highest value was with $75 \mathrm{~kg} / \mathrm{fed}$. seeding rate. This observation might be due to the $75 \mathrm{~kg} / \mathrm{fed}$. seed rate had more seeds $/ \mathrm{m}^{2}$ which in turn increased culms (main stems + tillers) number $/ \mathrm{m}^{2}$. In addition, the $75 \mathrm{~kg} / \mathrm{fed}$. seeding rate was more effective in controlling the competitive weeds (Table 2) which gave the chance to wheat plants to produce more tillers. This result is agreed with those obtained by Darwish et al. (2016). As for the interaction effect, Pallas treatment with 75 $\mathrm{kg} / \mathrm{fed}$. seed rate produced the highest number of stems $/ \mathrm{m}^{2}$ in both seasons, but the least value of stems number $/ \mathrm{m}^{2}$ resulted from the combined treatment of $45 \mathrm{~kg} / \mathrm{fed}$. seeding rate and without weed control in both seasons (Table 3).

\subsubsection{Spikes number $/ \mathrm{m}^{2}$}

Results in Table 4 show a significant increase in number of spikes $/ \mathrm{m}^{2}$ caused by Pallas treatment as compared to the control in both seasons. This result is agreed with that obtained by Aliaa et al. (2018). Ridges planting gave the highest number of spikes $/ \mathrm{m}^{2}$ in contrast to the other used planting methods in both seasons. However, the difference between ridges and rows was not significant in the $2^{\text {nd }}$ season (Table 4). Kabesh et al. (2009) and Rahman et al. (2010) found similar results. Inversely, the wet method produced the least 
number of spikes in both seasons. It is evident that the ridges-planting was superior in stimulating wheat plants to be more prolific spikes. Increasing seeding rate from 45 to 60 to $75 \mathrm{~kg} / \mathrm{fed}$. significantly and constantly increased spikes number $/ \mathrm{m}^{2}$ in both seasons. The $75 \mathrm{~kg} / \mathrm{fed}$. seed rate caused an increment of 76 and $91.6 \mathrm{spikes} / \mathrm{m}^{2}$ as compared to the usually used by farmers $(60$ $\mathrm{kg} / \mathrm{fed}$.) seed rate in the $1^{\text {st }}$ and $2^{\text {nd }}$ seasons, respectively. The interaction of $75 \mathrm{~kg} / \mathrm{fed}$. seed rate with Pallas herbicide significantly gave the highest spike number $/ \mathrm{m}^{2}$ in both seasons, while the least number of spikes was yielded from the combined treatment of $45 \mathrm{~kg} / \mathrm{fed}$. seeding rate and without weed control (Table 4).

\subsubsection{Grains number/spike}

The main effects of weed control, planting method, and seeding rate on the grains number/spike were almost significant in both seasons, except the weed control in the $1^{\text {st }}$ season (Table 5). Pallas application caused an increase in the number of grains/spike amounted for 3.2 and 13.6 grains/spike in $1^{\text {st }}$ and $2^{\text {nd }}$ seasons, respectively. Pallas herbicide made wheat-treated plots free from weeds which created proper environment for wheat plants having sufficient amounts of water, light, nutrients and other growth factors which in turn made them more yielding of grains/spike. Ridges planting significantly increased the number of grains/spike vs. the other used methods in both seasons. These results are in agreement with those obtained by EL-Sherif et al. (2016). Dry seeding method, however produced the least number of grains/spike in both seasons. In contrast to the effect of seeding rate on the number of spikes $/ \mathrm{m}^{2}$, the higher seeding rate of 75 $\mathrm{kg} / \mathrm{fed}$. gave significantly the least number of grains/spike in both seasons. Yet, the $45 \mathrm{~kg} / \mathrm{fed}$. produced the highest number of grains/spike. These results might be due to the compensation phenomenon appears among the yield components of grain yield that reported by Slafer et al. (1996). The findings of EL-Hag (2006) are supporting these results. The interaction effect of Pallas applied to the ridges plots which sown by 45 $\mathrm{kg} / \mathrm{fed}$. seeding rate produced the highest number of grains/spike in both seasons. On the other hand, $75 \mathrm{~kg} / \mathrm{fed}$. seed rate with dry seeding and without weeding control resulted in the least number of grains/spike in both seasons.

\subsubsection{Thousand grains weight}

Data presented in Table 6 show that chemical weeding by Pallas herbicide increased significantly the weight of thousand grains compared to the control in both seasons. This result would be due to that Pallas-treated plots were mostly free from weeds which caused a proper environment for wheat to grow and develop properly. Wheat planting methods significantly affected on 1000 grains weight in both seasons of study (Table 6). The ridges planting produced the highest 1000 grain weight followed by the rows method in both seasons. Yet, broadcasting (dry and wet seeding) methods resulted in the least 1000 grains weight. This result revealed that the ridges planting was ideal method for wheat stand establishment followed by the rows planting. Kamboj et al. (2017) reported similar results. Increasing seeding rate from 45 to 60 to $75 \mathrm{~kg} / \mathrm{fed}$. caused a steadily significant decrease in weight of 1000 grains in both seasons (Table 6). It is known that increasing the seeding rate increases the plant density which increases the intraspecific competition among wheat plants which causes a decrease in growth characteristics of individual plants. This result is agreed with that reported by EL-Hag (2006).

\subsubsection{Grain yield}

Data in Table 7 show the effects of weed control, planting method, seeding rate and their interactions on the grain yield in both seasons. The grain yield was expected as an outcome of the accumulative effects of spikes number $/ \mathrm{m}^{2}$, grains number/spike and mean weight of grain (from 1000 grain weight). A positive impact of Pallas herbicide was observed on grain yield (similarly as did with yield attributes) in contrast to the control in both seasons. The Pallas treatment caused increases in grain yield amounted for 4.4 and 6.4 
ardab/fed. in $1^{\text {st }}$ and $2^{\text {nd }}$ seasons, respectively. The more evident effect of Pallas herbicide in increasing grain yield in the $2^{\text {nd }}$ season in versus to the $1^{\text {st }}$ season effect might be due to the $2^{\text {nd }}$ season's site of the experiment was having more infested weeds and Pallas controlled them. This result is agreed with those reported by ElAshmouny et al. (2016). Ridges-planting was leading method for grain yield as compared to other methods used in this experiment in both seasons. Planting on ridges resulted in grain yield increases amounted for $1.15,4.7$ and 4.65 ardab/fed. (average of the two seasons) as compared to rows, dry and wet broadcast methods, respectively. These results are in agreement with those obtained by Marwat et al. (2011) and ElSherif et al. (2016). Increasing seeding rate from 45 to $75 \mathrm{~kg} / \mathrm{fed}$. had a steadily significant increase in grain yield/fed. in both seasons. Yet, the 75 $\mathrm{kg} / \mathrm{fed}$. seeding rate gave the highest grain yield/fed. with 1.5 and 3.75 ardab/fed. (average of the two seasons) increases over those of 60 and 45 $\mathrm{kg} / \mathrm{fed}$. seed rates, respectively. Similar results were obtained by Darwish et al. (2016) and IsidroSánchez et al. (2017). However, Baloch et al. (2010) and Tufa et al. (2019) reported that the effect of $150 \mathrm{~kg} / \mathrm{ha}$ seeding rate surpassed the effects of 100, 125, 175, or $200 \mathrm{~kg} / \mathrm{ha}$. Their different results than these results might be due to the different varieties they used and/or the different environments they grew wheat in. The interaction between weed control and planting method significantly affected the grain yield of wheat in both seasons of study. The ridges method with Pallas application had the highest grain yield as compared to the dry seeding method without weeding in both seasons. The grain yield responded significantly to the interaction effect between weed control and seeding rate in the $1^{\text {st }}$ season only. Whereas using $75 \mathrm{~kg} / \mathrm{fed}$. seeding rate with Pallas herbicide gave the highest grain yield (26.5 and 26.3 ardab/fed.) vs. $45 \mathrm{~kg} / \mathrm{fed}$. seeding rate without weed control in $1^{\text {st }}$ and $2^{\text {nd }}$ seasons, respectively. These results are in consistence with those reported by Aliaa et al. (2018). The $2^{\text {nd }}$ order interaction among the three studied factors exhibited a significant effect on the grain yield in the $2^{\text {nd }}$ season only. Averaged over the two seasons, the ridges planting with 75 $\mathrm{kg} / \mathrm{fed}$. seeding rate treated with Pallas herbicide produced the highest grain yield of 29.35 ardab/fed. (10.48 t/ha). On the contrary, the dry seeding method (afeer) seeded by $45 \mathrm{~kg} / \mathrm{fed}$. and without weed control resulted in the least grain yield (13.1 ardab/fed.).

\subsubsection{Lodged plants}

Visual observation of lodged plants at harvest indicated that: Wheat plants in Pallas-treated plots were stand and resistant to lodging in both seasons. Inversely, lodging was obvious in the unweeded plots. This observation might be due to the severe infested weeds in such plots that made wheat plants weak and more susceptible to lodge. Sowing wheat on ridges made plants more resistant to lodging. The good established rooting system, stiffness of stems and spatial plant distribution associated with ridges method might be the reasons for such observation. Similarly, row planting was the second after ridges. Yet, dry and wet planting methods were the worst in this respect. The highest seeding rate $(75 \mathrm{~kg} / \mathrm{fed}$.) made wheat plants more susceptible to lodging as compared to the lowest $45 \mathrm{~kg} / \mathrm{fed}$. seeding rate in both seasons. The increased intra-specific competition among wheat plants associated with the highest seeding rate which made plants weaker might be the reason for such observation. These observations on lodging might support and interpret the previously discussed results on grain yield and its attributes.

\section{Conclusion}

The ridges planting method with $75 \mathrm{~kg} / \mathrm{fed}$. seeding rate treated by Pallas herbicide satisfactorily controlled weeds and produced the highest grain yield of $29.35 \mathrm{ardab} / \mathrm{fed}$. (10.48 t/ha) and could be recommended as an integrated weed program for producing bread wheat under similar conditions. 


\section{Acknowledgment}

The authors thank and appreciate Prof.: Naheif E.

Mohamed (Agronomy Dep., Fac. Agric., Sohag
Univ., Egypt) for doing the statistical analysis of data collected from the work research of this manuscript.

Table 2. Impact of weed control, planting method, seeding rate and their interactions on dry weight of total weeds $\left(\mathrm{g} / \mathrm{m}^{2}\right)$ at 75 days of planting in 2016-17 and 2017-18 seasons.

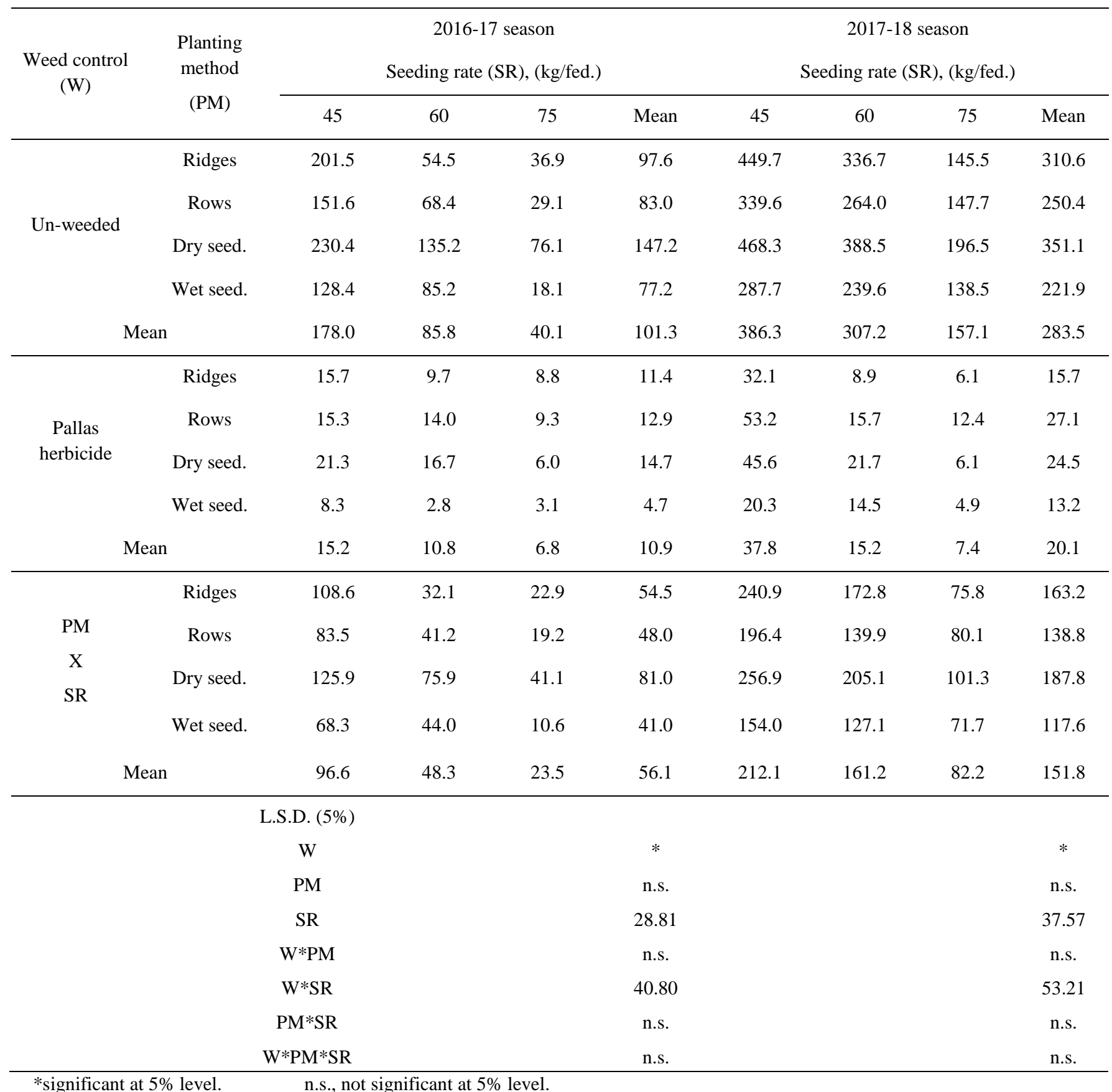


Table 3. Impact of weed control, planting method, seeding rate and their interactions on stems number/ $\mathrm{m}^{2}$ at harvest in 2016-17 and 2017-18 seasons.

\begin{tabular}{|c|c|c|c|c|c|c|c|c|c|}
\hline \multirow{2}{*}{$\begin{array}{l}\text { Weed } \\
\text { control } \\
(\mathrm{W})\end{array}$} & \multirow{2}{*}{$\begin{array}{l}\text { Planting } \\
\text { method } \\
(\mathrm{PM})\end{array}$} & \multicolumn{4}{|c|}{$\begin{array}{c}\text { 2016-17 season } \\
\text { Seeding rate }(\mathrm{SR}),(\mathrm{kg} / \mathrm{fed} .)\end{array}$} & \multicolumn{4}{|c|}{$\begin{array}{c}\text { 2017-18 season } \\
\text { Seeding rate }(\mathrm{SR}),(\mathrm{kg} / \mathrm{fed} .)\end{array}$} \\
\hline & & 45 & 60 & 75 & Mean & 45 & 60 & 75 & Mean \\
\hline \multirow{4}{*}{ Un-weeded } & Ridges & 369.5 & 451.0 & 536.0 & 452.2 & 269.5 & 348.5 & 414.0 & 344.0 \\
\hline & Rows & 359.5 & 455.5 & 519.0 & 444.7 & 244.0 & 329.5 & 411.0 & 328.2 \\
\hline & Dry seed. & 325.5 & 430.5 & 493.0 & 416.3 & 205.5 & 270.0 & 348.0 & 274.5 \\
\hline & Wet seed. & 367.5 & 407.5 & 458.5 & 411.2 & 200.5 & 256.5 & 313.0 & 256.7 \\
\hline \multicolumn{2}{|c|}{ Mean } & 355.5 & 436.1 & 501.6 & 431.1 & 229.9 & 301.1 & 371.5 & 300.8 \\
\hline \multirow{4}{*}{$\begin{array}{c}\text { Pallas } \\
\text { herbicide }\end{array}$} & Ridges & 403.5 & 503.5 & 635.0 & 514.0 & 300.5 & 396.5 & 515.5 & 404.2 \\
\hline & Rows & 380.5 & 471.0 & 572.0 & 474.5 & 302.0 & 370.0 & 485.5 & 385.8 \\
\hline & Dry seed. & 381.5 & 454.5 & 556.0 & 464.0 & 226.0 & 308.5 & 435.0 & 323.2 \\
\hline & Wet seed. & 358.5 & 439.5 & 515.5 & 437.8 & 209.0 & 262.0 & 411.5 & 294.2 \\
\hline \multicolumn{2}{|c|}{ Mean } & 381.0 & 467.1 & 569.6 & 472.6 & 259.4 & 334.3 & 461.9 & 351.8 \\
\hline \multirow{13}{*}{$\begin{array}{c}\mathrm{PM} \\
\mathrm{X} \\
\mathrm{SR}\end{array}$} & Ridges & 386.5 & 477.3 & 585.5 & 483.1 & 285.0 & 372.5 & 464.8 & 374.1 \\
\hline & Rows & 370.0 & 463.3 & 545.5 & 459.6 & 273.0 & 349.8 & 448.3 & 357.0 \\
\hline & Dry seed. & 353.5 & 442.5 & 524.5 & 440.2 & 215.8 & 289.3 & 391.5 & 298.9 \\
\hline & Wet seed. & 363.0 & 423.5 & 487.0 & 424.5 & 204.8 & 259.3 & 362.3 & 275.5 \\
\hline & & 368.3 & 451.6 & 535.6 & 451.8 & 244.7 & 317.7 & 416.7 & 326.4 \\
\hline & \multicolumn{3}{|c|}{ L.S.D. (5\%) } & & & & & & \\
\hline & \multicolumn{3}{|c|}{ W } & & $*$ & & & & $*$ \\
\hline & \multicolumn{2}{|r|}{ PM } & & & 22.64 & & & & 17.15 \\
\hline & \multicolumn{2}{|r|}{ SR } & & & 16.86 & & & & 12.03 \\
\hline & \multicolumn{2}{|r|}{$\mathrm{W} * \mathrm{PM}$} & & & n.s. & & & & n.s. \\
\hline & \multicolumn{2}{|r|}{$\mathrm{W} * \mathrm{SR}$} & & & 23.96 & & & & 17.08 \\
\hline & \multicolumn{2}{|r|}{$\mathrm{PM} * \mathrm{SR}$} & & & n.s. & & & & n.s. \\
\hline & \multicolumn{2}{|r|}{$\mathrm{W} * \mathrm{PM} * \mathrm{SR}$} & & & n.s. & & & & n.s. \\
\hline
\end{tabular}

\footnotetext{
*significant at 5\% level.
} n.s., not significant at $5 \%$ level. 
Table 4. Impact of weed control, planting method, seeding rate and their interactions on spikes number/m ${ }^{2}$ in 2016-17 and 2017-18 seasons.

\begin{tabular}{|c|c|c|c|c|c|c|c|c|c|}
\hline \multirow{2}{*}{$\begin{array}{l}\text { Weed control } \\
\text { (W) }\end{array}$} & \multirow{2}{*}{$\begin{array}{l}\text { Planting } \\
\text { method } \\
(\mathrm{PM})\end{array}$} & \multicolumn{4}{|c|}{$\begin{array}{c}\text { 2016-17 season } \\
\text { Seeding rate }(\mathrm{SR}),(\mathrm{kg} / \mathrm{fed} .)\end{array}$} & \multicolumn{4}{|c|}{$\begin{array}{c}\text { 2017-18 season } \\
\text { Seeding rate }(\mathrm{SR}),(\mathrm{kg} / \mathrm{fed} .)\end{array}$} \\
\hline & & 45 & 60 & 75 & Mean & 45 & 60 & 75 & Mean \\
\hline \multirow{4}{*}{ Un-weeded } & Ridges & 363.5 & 437.0 & 511.0 & 437.2 & 264.0 & 335.0 & 395.5 & 331.5 \\
\hline & Rows & 350.0 & 428.5 & 490.5 & 423.0 & 238.0 & 316.5 & 390.5 & 315.0 \\
\hline & Dry seed. & 318.0 & 412.0 & 464.0 & 398.0 & 198.0 & 250.0 & 316.0 & 254.7 \\
\hline & Wet seed. & 308.5 & 395.0 & 439.5 & 381.0 & 198.5 & 246.0 & 297.5 & 247.3 \\
\hline \multicolumn{2}{|c|}{ Mean } & 335.0 & 418.1 & 476.3 & 409.8 & 224.6 & 286.9 & 349.9 & 287.1 \\
\hline \multirow{4}{*}{$\begin{array}{l}\text { Pallas } \\
\text { herbicide }\end{array}$} & Ridges & 398.5 & 488.0 & 610.0 & 498.8 & 295.0 & 383.0 & 495.5 & 391.2 \\
\hline & Rows & 375.0 & 459.5 & 552.5 & 462.3 & 297.5 & 362.0 & 467.0 & 375.5 \\
\hline & Dry seed. & 368.0 & 433.5 & 528.5 & 443.3 & 220.5 & 302.0 & 417.0 & 313.2 \\
\hline & Wet seed. & 353.0 & 424.5 & 490.5 & 422.7 & 205.0 & 253.5 & 401.5 & 286.7 \\
\hline \multicolumn{2}{|c|}{ Mean } & 373.6 & 451.4 & 545.4 & 456.8 & 254.5 & 325.1 & 445.3 & 341.6 \\
\hline \multirow{13}{*}{$\begin{array}{c}\mathrm{PM} \\
\mathrm{X} \\
\mathrm{SR}\end{array}$} & Ridges & 381.0 & 462.5 & 560.5 & 468.0 & 279.5 & 359.0 & 445.5 & 361.3 \\
\hline & Rows & 362.5 & 444.0 & 521.5 & 442.7 & 267.8 & 339.3 & 428.8 & 345.3 \\
\hline & Dry seed. & 343.0 & 422.8 & 496.3 & 420.7 & 209.3 & 276.0 & 366.5 & 283.9 \\
\hline & Wet seed. & 330.8 & 409.8 & 465.0 & 401.8 & 201.8 & 249.8 & 349.5 & 267.0 \\
\hline & & 354.3 & 434.8 & 510.8 & 433.3 & 239.6 & 306.0 & 397.6 & 314.4 \\
\hline & \multicolumn{3}{|c|}{ L.S.D. $(5 \%)$} & & & & & & \\
\hline & \multicolumn{3}{|c|}{ W } & & $* *$ & & & & $* *$ \\
\hline & \multicolumn{2}{|c|}{$\mathrm{PM}$} & & & 15.02 & & & & 16.89 \\
\hline & \multicolumn{2}{|c|}{ SR } & & & 12.05 & & & & 12.21 \\
\hline & \multicolumn{2}{|c|}{$\mathrm{W} * \mathrm{PM}$} & & & n.s. & & & & n.s. \\
\hline & \multicolumn{2}{|c|}{$\mathrm{W} * \mathrm{SR}$} & & & 17.12 & & & & 17.35 \\
\hline & \multicolumn{2}{|c|}{$\mathrm{PM} * \mathrm{SR}$} & & & n.s. & & & & n.s. \\
\hline & \multicolumn{2}{|c|}{$\mathrm{W} * \mathrm{PM} * \mathrm{SR}$} & & & n.s. & & & & n.s. \\
\hline
\end{tabular}

**significant at $1 \%$ level. $\quad$ n.s., not significant at $5 \%$ level. 
Table 5. Impact of weed control, planting method, seeding rate and their interactions on number of grains/spike in 2016-17 and 201718 seasons.

\begin{tabular}{|c|c|c|c|c|c|c|c|c|c|}
\hline \multirow{2}{*}{$\begin{array}{l}\text { Weed control } \\
\text { (W) }\end{array}$} & \multirow{2}{*}{$\begin{array}{l}\text { Planting } \\
\text { method } \\
(\mathrm{PM})\end{array}$} & \multicolumn{4}{|c|}{$\begin{array}{c}\text { 2016-17 season } \\
\text { Seeding rate }(\mathrm{SR}),(\mathrm{kg} / \mathrm{fed} .)\end{array}$} & \multicolumn{4}{|c|}{$\begin{array}{c}\text { 2017-18 season } \\
\text { Seeding rate }(\mathrm{SR}),(\mathrm{kg} / \mathrm{fed} .)\end{array}$} \\
\hline & & 45 & 60 & 75 & Mean & 45 & 60 & 75 & Mean \\
\hline \multirow{4}{*}{ Un-weeded } & Ridges & 94.7 & 88.6 & 79.9 & 87.7 & 92.8 & 85.6 & 81.6 & 86.7 \\
\hline & Rows & 91.7 & 81.9 & 78.1 & 83.9 & 90.9 & 84.2 & 80.3 & 85.1 \\
\hline & Dry seed. & 83.9 & 78.6 & 71.6 & 78.0 & 83.9 & 79.4 & 72.2 & 78.5 \\
\hline & Wet seed. & 89.8 & 81.8 & 74.2 & 81.9 & 87.2 & 82.6 & 77.5 & 82.4 \\
\hline \multicolumn{2}{|c|}{ Mean } & 90.0 & 82.7 & 76.0 & 82.9 & 88.7 & 83.0 & 77.9 & 83.2 \\
\hline \multirow{5}{*}{$\begin{array}{c}\text { Pallas } \\
\text { herbicide }\end{array}$} & Ridges & 100.8 & 92.7 & 85.8 & 93.1 & 105.7 & 102.5 & 98.3 & 102.2 \\
\hline & Rows & 93.5 & 84.2 & 79.8 & 85.8 & 103.1 & 96.9 & 91.5 & 97.2 \\
\hline & Dry seed. & 86.4 & 80.9 & 73.8 & 80.4 & 95.6 & 93.2 & 89.5 & 92.8 \\
\hline & Wet seed. & 91.7 & 83.8 & 80.0 & 85.2 & 98.9 & 94.8 & 91.1 & 94.9 \\
\hline & & 93.1 & 85.4 & 79.9 & 86.1 & 100.8 & 96.9 & 92.6 & 96.8 \\
\hline \multirow{13}{*}{$\begin{array}{l}\text { PM } \\
X \\
\text { SR }\end{array}$} & Ridges & 97.8 & 90.7 & 82.8 & 90.4 & 99.2 & 94.0 & 89.9 & 94.4 \\
\hline & Rows & 92.6 & 83.0 & 79.0 & 84.9 & 97.0 & 90.6 & 85.9 & 91.2 \\
\hline & Dry seed. & 85.1 & 79.7 & 72.7 & 79.2 & 89.7 & 86.3 & 80.9 & 85.6 \\
\hline & Wet seed. & 90.8 & 82.8 & 77.1 & 83.6 & 93.0 & 88.7 & 84.3 & 88.7 \\
\hline & & 91.6 & 84.1 & 77.9 & 84.5 & 94.7 & 89.9 & 85.3 & 90.0 \\
\hline & \multicolumn{2}{|c|}{ L.S.D. (5\%) } & & & & & & & \\
\hline & \multicolumn{2}{|c|}{ W } & & & n.s. & & & & $* *$ \\
\hline & \multicolumn{2}{|c|}{ PM } & & & 3.08 & & & & 1.47 \\
\hline & \multicolumn{2}{|c|}{ SR } & & & 2.51 & & & & 1.55 \\
\hline & \multicolumn{2}{|c|}{$\mathrm{W} * \mathrm{PM}$} & & & n.s. & & & & n.s. \\
\hline & \multicolumn{2}{|c|}{$\mathrm{W} * \mathrm{SR}$} & & & n.s. & & & & n.s. \\
\hline & \multicolumn{2}{|c|}{$\mathrm{PM} * \mathrm{SR}$} & & & n.s. & & & & n.s. \\
\hline & \multicolumn{2}{|c|}{$\mathrm{W} * \mathrm{PM} * \mathrm{SR}$} & & & n.s. & & & & n.s. \\
\hline
\end{tabular}


Table 6. Impact of weed control, planting method, seeding rate and their interactions on weight of 1000- grain (g) in 2016-17 and 2017-18 seasons.

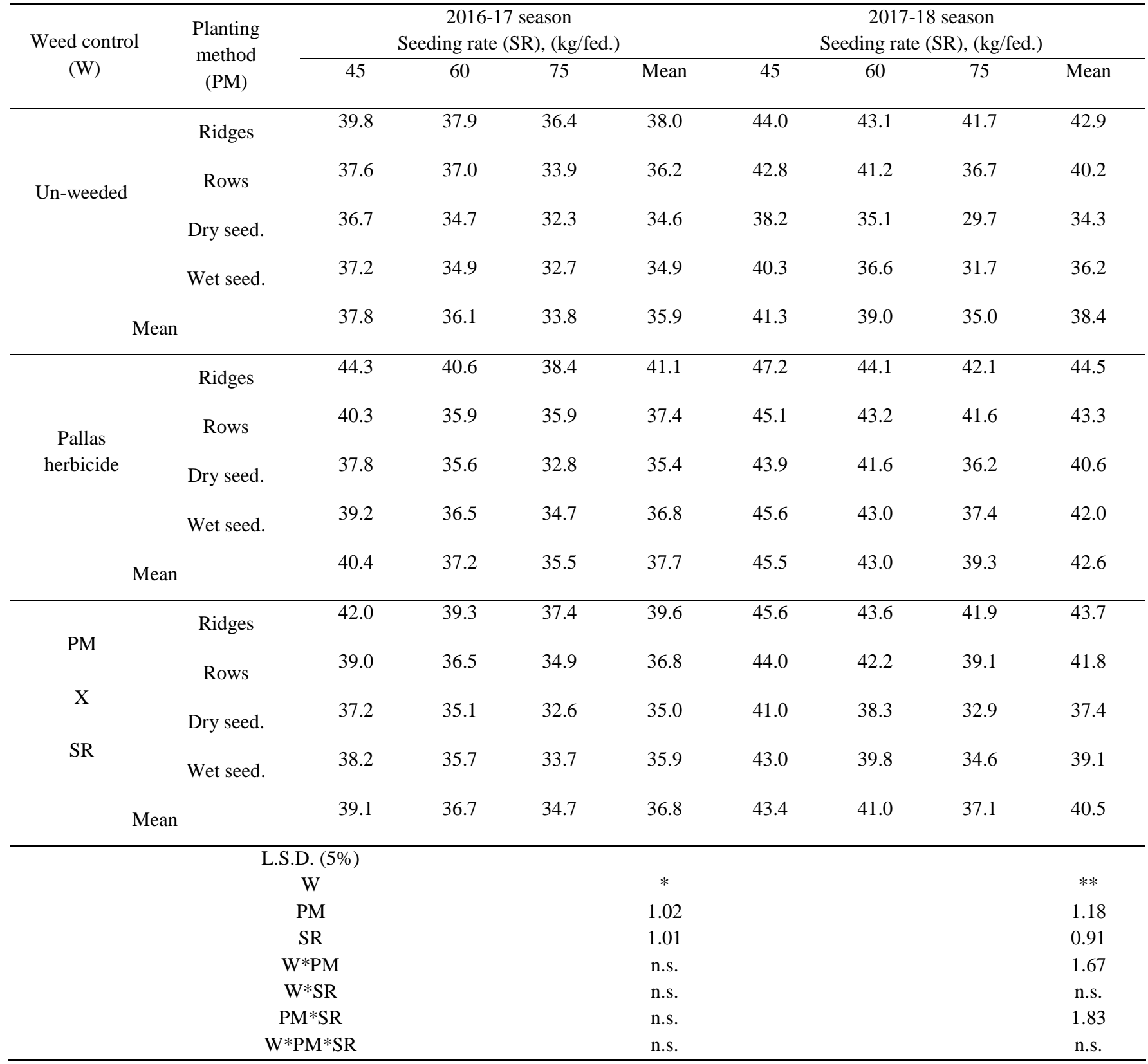

*significant at $5 \%$ level. **significant at $1 \%$ level. $\quad$ n.s., not significant at $5 \%$ level. 
Table 7. Impact of weed control, planting method, seeding rate and their interactions on grain yield (ardab/fed.) in 2016-17 and 201718 seasons.

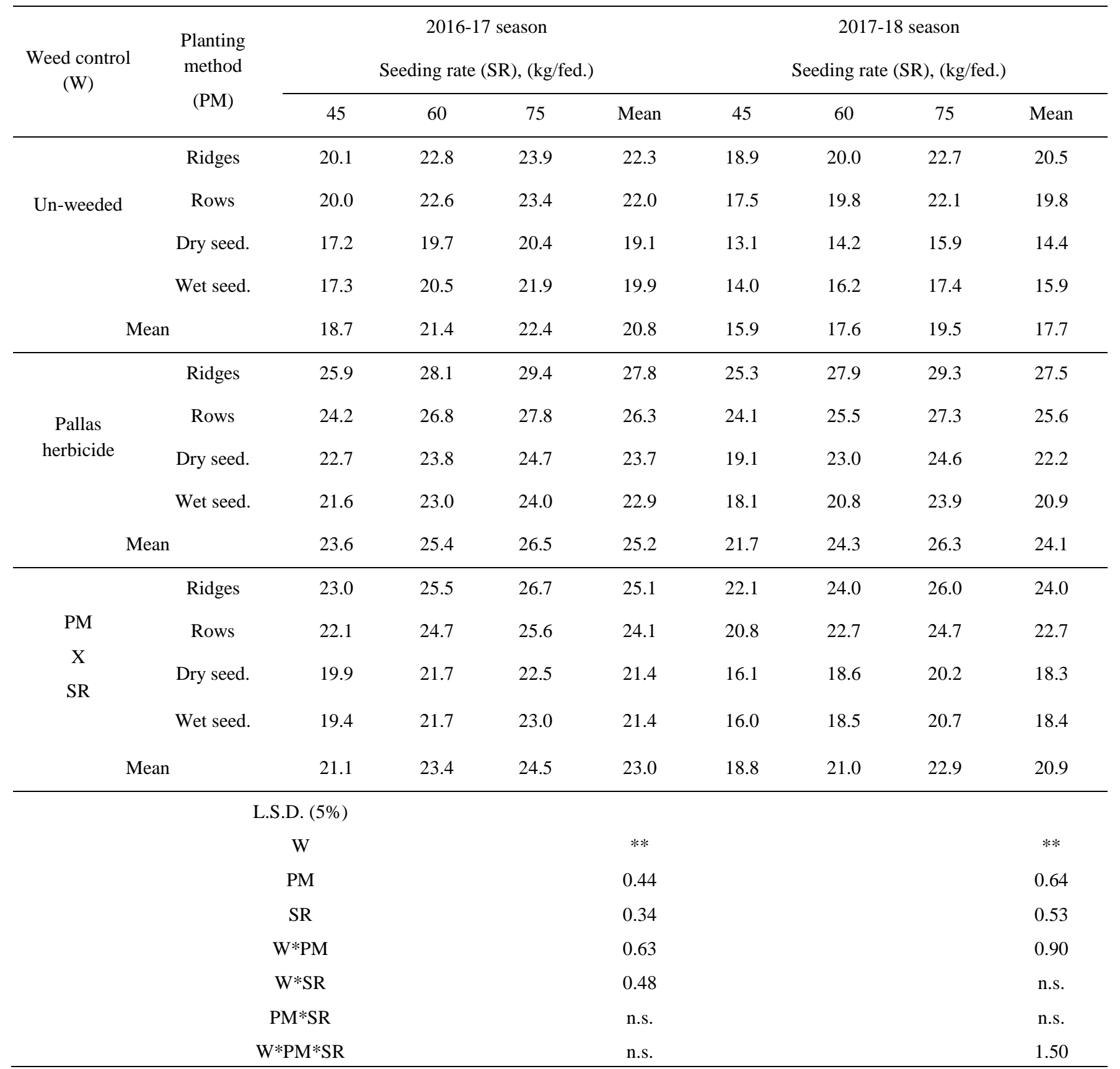

\footnotetext{
***significant at $1 \%$ level. $\quad$ n.s., not significant at $5 \%$ level.
}

\section{References}

Abdul-Hamid, A.M. (2021) 'Impact of planting method, seeding rate and chemical weed control on productivity of bread wheat and associated weeds' M.Sc. Thesis, Fac. Agric. Sohag Univ., Egypt.

Aliaa, Kh.M, Yassin, A.A., Hussain, M.M., Imad, Kh.H., Hassan, A.F. and. Modhfar, A.A. (2018) 'Effect herbicides, seeding rates and reflection on wheat yield' Journal of Education and Scientific Studies, 1(12). Anonymous (2007) 'Pyroxsulam, Tech. Bull., 2007', Dow Agro Sciences:

http://www.dowagro.com

Baloch, M.S., Shah, I.T.H., Nadim, M.A., Khan, M.I. and Khakwani, A.A. (2010) 'Effect of seeding density and planting time on growth and yield attributes of wheat' J. Anim. Plant Sci., 20(4), pp.239-242. 
Chauhdary, J.N., Khan, U.D., Shah, S.H.H., Shahid, M.A. and Arsalan, M. (2016) 'Effect of sowing methods and seed rates on wheat yield and water productivity' Quality Assurance and Safety of Crops \& Foods, 8(2), pp.267-272.

Darwish, G.G., AtaAllah, S.A.A., Abdullah, S.Sh. and Younis, A.A.M. (2016) 'Response of durum wheat and associated weeds to some weeds control treatments under various seeding rates' Annals of Agricultural Sciences, Moshtohor, 45(4): 841-852

El-Ashmouny, M.S., Tantawy, A.A., Salem, M.A. and Hussien, O.M. (2016) 'Effect of sowing and weed control methods on yield and its components of some bread wheat cultivars' El-Minia Journal of Agricultural Research and Development, 36(4), pp.551-563.

El-Bana, A.A., Sadiq, I.M., and Mostafa, M.A. (2013) (In Arabic): 'The final report of National Program for Raising Wheat Production and National Project of Extension Fields' Agric. Res. Center, Ministry. Agric. Land Reclaim., Egypt.

El-Hag, A.A. (2006) 'The influence of seeding rate on yield and its components of some Egyptian wheat cultivars' J. Agric. Res., Tanta Univ., 32(1), pp.76-89.

El-Sherif, S.T.I., El-Areed, SH.R.M., Hagras, A.A., Mohamed, M.M. and Abd El-Hameed, A.S. (2016) 'Impact of planting method on grain yield and yield components of different bread wheat genotypes' Egypt. J. Plant Breed. 20(5):805-819.

FAO (2018) 'Food balance sheet of Egypt' http://www.fao.org/faostat/en/\#data/FBS

FAO (2019) 'FAOSTAT data (crops)' http://www.fao.org/faostat/en/\#data/QC

Gomez, K.A. and Gomez, A.A. (1984) 'Statistical procedures for agricultural research' John Wiley \& Sons., N.Y., USA.

Hossain, M.M. (2015) 'Recent perspective of herbicide: Review of demand and adoption in world agriculture' Journal of the Bangladesh Agricultural University, 13(4522016-35850), pp.13-24.

Isidro-Sánchez, J., Perry, B., Singh, A.K., Wang, H., DePauw, R.M., Pozniak, C.J., Beres, B.L., Johnson, E.N. and Cuthbert, R.D. (2017) 'Effects of seeding rate on durum crop production and physiological responses' Agron. J., 109(5), pp.1981-1990.

Kabesh, M.O., El-Kramany, M.F., Sary, G.A., ElNaggar, H.M. and Gehan, S.H.B. (2009) 'Effects of sowing methods and some bioorganic fertilization treatments on yield and yield components of wheat' Res. J. Agric. Biol. Sci., 5(1), pp.97-102.

Kamboj, N.K., Hooda, V.S., Gupta, G., Devi, S. and Jinger, D. (2017) 'Performance of wheat under different planting methods and weed management practices' Ann. Agric. Res. New Series, 38 (1): 31-37.

Marwat, K.B., Khan, M.A., Hashim, S., Nawab, K. and Khattak, A.M. (2011) 'Integrated weed management in wheat' Pak. J. Bot, 43(1), pp.625-633.

Mobarak, O.M.M. (2008) 'Effect of sowing methods, fertilization and some weed control treatments on wheat productivity' M.Sc. Thesis, Fac. Agric., El-Minia Univ., Egypt.

Mollah, M.I.U., Bhuiya, M.S.U. and Kabir, M.H. (2009) 'Bed planting a new crop establishment method for wheat in ricewheat cropping system' J. Agric. \& Rural Develop., 7(1\&2): pp.23-31.

Rahman, M.A., Hossain, S.J., Hossain, M.B., Amin, M.R. and Sarkar, K.K. (2010) 'Effect of variety and culture method on the yield and yield attributes of wheat' Int. J. Sustain. Crop Prod., 5(3), pp.17-21.

SAS Institute (2008) 'The SAS system for Windows, Release 9.2' SAS Institute.

Slafer, G.A., Calderini, D.F. and Miralles, D.J. (1996) 'Yield components and compensation in wheat: opportunities for further increasing yield potential' Increasing yield potential in wheat: Breaking the Barriers, pp.101-133.

Tufa, T., Kumbi, H. and. Abera, T., (2019) 'Influence of seed rate and row spacing on growth and yield of bread wheat in Chelia District of West Showa Zone' Ethiopia. J. Nat. Sci. Res.,.9 (5).

Yadav, M.K. and Jagdish, C., (2015) 'Effect of herbicides and row spacing on weed dynamics and productivity of bread wheat (Triticum aestivum L.)' Advance Research Journal of Crop Improvement, 6(2), pp.7377. 